\title{
SIMULATION DECISION GAMES AND EFFECTIVENESS OF THEIR USE FOR HIGHER EDUCATION - THEORETICAL VIEW
}

\author{
Monika STOMA ${ }^{1}$, Agnieszka DUDZIAK ${ }^{2 *}$, Leszek RYDZAK ${ }^{3}$ \\ ${ }^{1}$ University of Life Sciences in Lublin, Department of Power Engineering and Transportation, Subdepartment of \\ Logistics and Business Management; monika.stoma@up.lublin.pl; ORCID: 0000-0003-0404-699X \\ ${ }^{2}$ University of Life Sciences in Lublin, Department of Power Engineering and Transportation, Subdepartment of \\ Logistics and Business Management agnieszka.dudziak@up.lublin.pl; ORCID: 0000-0002-4884-5403 \\ ${ }^{3}$ University of Life Sciences in Lublin, Department of Food Engineering and Machinery; \\ leszek.rydzak@up.lublin.pl, ORCID: 0000-0002-9359-4412 \\ * Correspondence author
}

Purpose: The article presents the essence, characteristics and types of simulation decision games, as well as the effectiveness of their use in academic conditions in the theoretical context. Design/methodology/approach: The article is based of analysis of research results published in national and world publications.

Findings: The didactic process carried out at universities with the use of direct forms of teaching can be supported by additional tools, including simulation decision games, because it brings many benefits in different areas. By playing we are able to learn many issues in a natural way, to refer to the mechanisms of the organization's functioning, and to use - sometimes dormant - soft competences of game participants.

Research limitations/implications: It is advisable to carry out further scientific research in the field of using simulation games due to the fact that they are increasingly used as a tool to support the process of practical learning. Despite its popularity, the assessment of the effectiveness of using simulation games as an educational or training tool is still unclear.

Social implications: Game-based learning (GBL) is used not only in higher education (especially in a wide range of economic and management disciplines, such as: marketing, economics, international business, project management, strategic management or human resources management), but also in other fields, including: army, education, advertising, trade, medicine and employee training.

Originality/value: The work is theoretical. However, the problem raised in the article, in the context of new challenges posed by teachers in the teaching process, is an inspiring introduction to further research.

Keywords: simulation games, gamification, game-based learning, higher education, competences.

Category of the paper: Research paper. 


\section{The essence of simulation decision games}

Simulation educational games are experimental exercises that move participants to another world, in which they use their knowledge, skills and strategies to perform their assigned roles. According to Gredler (2004), simulation games were first used for educational purposes in the 17 th century in the form of war games. Their goal was to improve the strategic planning of the army and navy. At the end of the 1950s, the use of simulation became the basis of business education, and since then games and simulations can be found in education (in many different scientific disciplines) and corporate trainings.

In the literature, many different definitions of simulation strategic games or simulation decision games can be found; these are both "broad" definitions, describing in detail the essence of this concept and indicating its key features, as well as "narrow" definitions, emphasizing above all the importance of rules. Moreover, the use of different terminology in relation to this concept may be noted; in addition to the above mentioned, terms such as: management simulations, business simulations, business games or "serious" games are also used. Table 1 summarizes several concepts of the term "simulation game" according to different authors.

Table 1.

Selected definitions of the term "simulation game"

\begin{tabular}{|c|c|}
\hline $\begin{array}{c}\text { Author, year of } \\
\text { publication }\end{array}$ & Definition \\
\hline $\begin{array}{l}\text { Babb, Leslie \& } \\
\text { Van Slyke, } 1966\end{array}$ & $\begin{array}{l}\text { Business games are decision exercises in which teams compete in meeting specific } \\
\text { goals, and players make sequential management decisions that affect their current and } \\
\text { future positions. }\end{array}$ \\
\hline $\begin{array}{l}\text { Armstrong \& } \\
\text { Hobson, } 1974\end{array}$ & $\begin{array}{l}\text { Gaming simulation is characterized by the presence of all the listed elements: role } \\
\text { definitions, scenario, calculation system, roles and procedures structuring participants } \\
\text { of the exercise. }\end{array}$ \\
\hline Walkowiak, 1981 & $\begin{array}{l}\text { Simulation decision game is a simulation with an unlimited area of applicability, } \\
\text { in which there are people-participants who make decisions within a simulated system } \\
\text { according to specific rules, wherein the purpose of the game and the previous states of } \\
\text { the simulated real or hypothetical subject system are known. }\end{array}$ \\
\hline Metera et al., 1983 & $\begin{array}{l}\text { Simulation decision game is a situation in which people occur as participants making } \\
\text { decisions within a simulated system, whereby the following conditions are fulfilled: } \\
\text { (a) the goal of the game is defined, (b) the dynamic model of the simulated system is } \\
\text { determined; (c) the participants are part of the model, (d) drama is defined in the form } \\
\text { of game rules, (e) a summary of the game is made and planned, (f) there is the game } \\
\text { management. }\end{array}$ \\
\hline Larréché, 1987 & $\begin{array}{l}\text { Decision game is a tool that allows individuals to use and develop decision-making } \\
\text { skills in a fictitious competitive environment. }\end{array}$ \\
\hline Gredler, 2004 & $\begin{array}{l}\text { "Simulations are open-ended evolving situations with many interacting variables. The } \\
\text { goal for all participants is to each take a particular role, address the issues, threats, or } \\
\text { problems that arise in the situation, and experience the effects of their decisions. The } \\
\text { situation can take different directions, depending on the actions and reactions of the } \\
\text { participants." }\end{array}$ \\
\hline
\end{tabular}


The diversity of terms "simulation game" results from the complexity and multidimensionality of this concept, and none of the definitions fully conveys all the features of simulation games. This is also reflected in the numerous typologies of these games, constructed on the basis of a broad spectrum of criteria: the scope of the game (games about the entire organization and games focusing on a single company subdivision) (Keys \& Wolfe, 1990), the number of people solving the problem (single and team games), the number of organizational levels whose managers participate in the game (single, double and multi-level games), the number of sides affecting the solved problem (single-, double- and multilateral games), the number of stages (one, two and multi-stage), the division of the impact of players' decisions on the results of the simulation model (games without cooperation and interaction games, which in turn are divided into competitive and cooperative games).

Another typology of simulation games was proposed by Lean with the team (2006), who took into account previous studies of other authors included in the literature on the subject, which is presented in Figure 1.

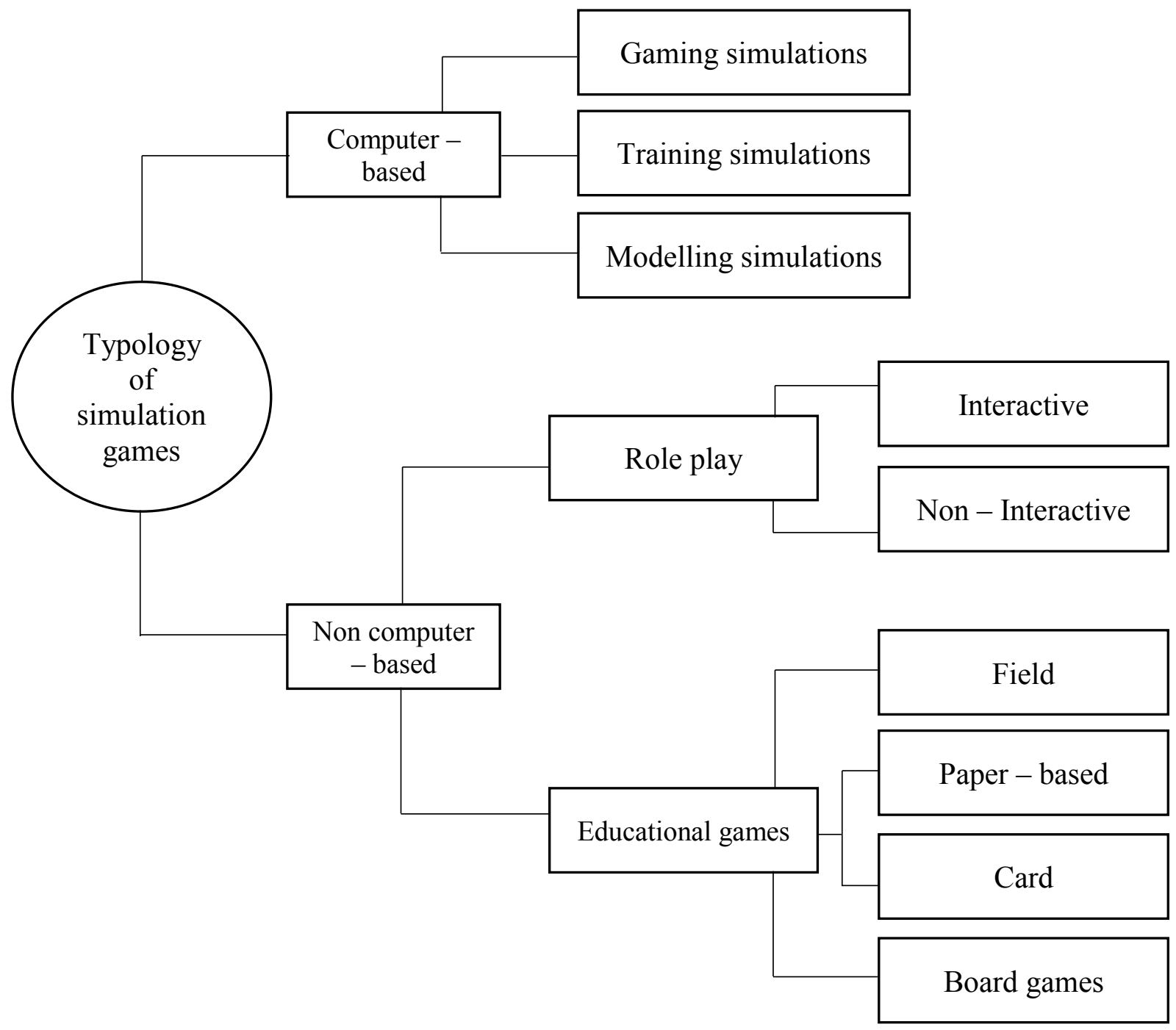

Figure 1. Typology of simulation games. Adapted from: Lean, J., Moizer, J., Towler, M., Abbey C. (2006). Simulations and games. Active Learning in Higher Education, SAGE Publications, 7 (3), $227-$ 242. Doi:10.1177/1469787406069056.spacing). 
In the literature, for several dozen years, there has also been a dichotomic division of simulation games into so-called "serious games" and entertainment games (Abt, 1971). Simulation training games used for educational purposes at universities belong to the first type of games. They have utilitarian and heterotelic nature, and their overarching goal is to support the learning process, including mainly shaping and developing skills and competences.

To sum up the essence of simulation strategic games, it can be stated that they are a tool whose objective is to offer students the opportunity to learn by acting, engaging them in simulated situations occurring in the real world (Ben-Zvi, 2010).

\section{Specific features of simulation decision games}

Regardless of the used definition, all simulation training games, applied among others in the teaching process in higher education, are characterized by several specific features, such as: goal, mechanism, principles (scenario), accomplishment, feedback, interaction and competences (Prensky, 2001). These features are described in table 2.

Table 2.

Characteristics of simulation training games

\begin{tabular}{|c|c|}
\hline \multicolumn{2}{|r|}{ Characteristics of simulation games } \\
\hline $\begin{array}{l}\text { The goal of the } \\
\text { game }\end{array}$ & $\begin{array}{l}\text { It is designated to participants. In the case of training games, the goals are most often } \\
\text { constructed based on conflict and competition. The task of the players is to resolve the } \\
\text { conflict or win with the competition (for example, a different company, team, } \\
\text { department or tribe). }\end{array}$ \\
\hline $\begin{array}{l}\text { The mechanism } \\
\text { of the game }\end{array}$ & $\begin{array}{l}\text { Defined dynamic model of the system - refers to various types of obstacles, barriers and } \\
\text { challenges that are incorporated into the game, such as time restrictions, resource } \\
\text { restrictions (e.g. materials necessary to perform a task), inconsistent information, } \\
\text { an ineffective communication system between players, or other restrictions imposed by } \\
\text { the rules of the game, and whose overcoming allows you to end the game successfully. }\end{array}$ \\
\hline Game rules & $\begin{array}{l}\text { The rules of the game determine the actions that are allowed or prohibited in the game } \\
\text { and the consequences of taking such actions. They can, for example, determine when } \\
\text { teams participating in the game can communicate with each other, what is the order of } \\
\text { actions, etc. As part of the rules, there may also be a point scoring system or other } \\
\text { mechanism that allows you to select the winner of the game - the result achieved at } \\
\text { a specific point in the game reflects the user's progress and skills. }\end{array}$ \\
\hline Accomplishment & $\begin{array}{l}\text { Every game once comes to an end. What is responsible for this is so-called "ending rule" } \\
\text { specifying the moment and way of ending the game, and in consequence the way of } \\
\text { selecting the winner or determining the benefits achieved by the participants. It can be } \\
\text { a time intended for gameplay, reaching a goal or a certain number of points. However, } \\
\text { it is not yet transferring the results achieved in the game to the professional or life } \\
\text { situation of the participants. }\end{array}$ \\
\hline Interaction & $\begin{array}{l}\text { Interaction is an element that on the one hand distinguishes the games from other } \\
\text { training forms, and on the other hand it determines their attractiveness for participants. } \\
\text { It may have the character of interaction of teams, individual participants, or interaction } \\
\text { with the system, e.g. a computer application. }\end{array}$ \\
\hline Competences & $\begin{array}{l}\text { The game can be considered as a training game if its construction allows the } \\
\text { development of players' competences, in which discussing the game, drawing } \\
\text { conclusions and attempt to translate the results into the professional or personal reality of } \\
\text { participants is helpful. }\end{array}$ \\
\hline
\end{tabular}


As can be seen from the information in Table 2, the development of competence of participants in simulation decision games is an important element of training games (Szewczak, 2015), and discussing the game is the most important stage in the implementation of the game (Tchatcher, 1986; Wentzler and Chartier, 1999). In the discussing phase of the game, the moderator or game supervisor should pay particular attention to the aspects of competition and cooperation, as well as identify factors that have helped or hinder the achievement of goals. Each time, it should be remembered that there is no universal framework for discussing each game. The specific character of simulated strategic games causes that the observations, remarks and conclusions of participants, and even the general impression appearing after the end of the game, will depend on their previous experience, acquired knowledge and their competences and skills. In addition, even the same games, but conducted in different conditions, in other groups, at different times - often allow for the development of different conclusions in different areas, especially such as: team collaboration, cooperation between teams, competition, work under time pressure, proper work organization, division of roles in a team, development and consistent implementation of a strategy, as well as decision-making and motivating.

As Świtalski claimed in $1977, \mathrm{G}_{\mathrm{sim} 1} \neq \mathrm{G}_{\mathrm{sim}} 2$ if $\mathrm{G}_{\mathrm{sim} 1}=<\mathrm{D}, \mathrm{M}, \mathrm{R}, \mathrm{T}_{1}>$ and $\mathrm{G}_{\mathrm{sim} 2}=<\mathrm{D}, \mathrm{M}, \mathrm{R}, \mathrm{T}_{2}>$ and $\mathrm{T}_{1}=\mathrm{T}_{2}$ (where Gsim - simulation game, $\mathrm{D}$ - objective domain, which is represented by the game, $\mathrm{M}$ - subject field model, $\mathrm{R}$ - game rules, $\mathrm{T}$ - mechanism and technique of conducting the game). This means that each game is unique and putting an equal sign between any two simulation games (even based on the same rules and the same model), requires the assumption about the negligible differences between the methods of the games (Świtalski, 1977).

It should be added that the specific feature that distinguishes simulation games from other simulation models is the place and role of a human being who is not only a user but also a part of the simulation game model. Decisions made by a human - participant enrich the model; role playing has a conscious character here, and the role itself (understood as a suggestion of the game designer) is only one of many factors influencing its final implementation (Balcerak and Pełech, 2000).

In conclusion, it should be stated that every simulation training game must have a specific goal that can be achieved by acting in accordance with the rules of the game, which is hampered by various "inefficiencies" or challenges posed by the game mechanism. During the game, its participants enter into various types of interactions, which - together with drawing conclusions - leads to the development of competences. This, in turn, is the main purpose of using this type of form in the teaching process at universities. 


\section{Effectiveness of the use of simulation training games in higher education}

Simulation games used in the didactic process at universities can fulfil one of four basic goals: (a) to practice and/or improve already acquired knowledge and skills, (b) to identify gaps or deficiencies in knowledge or skills, (c) to serve as summary or review, and (d) to develop new relationships between concepts and principles (Gredler, 2004). Therefore, they generate a lot of different benefits, among which the following can be mentioned:

- making the didactic process more attractive,

- facilitating the learning process,

- acquiring new knowledge and new competences,

- developing already existing competences,

- learning by solving real problems,

- learning by playing,

- the possibility of using the already existing theoretical and practical knowledge the opportunity to practice the theory in practice,

- gathering experience by action,

- the ability to play different roles,

- group integration.

As mentioned above, simulation training games on the one hand can make the didactic process at universities more attractive, and on the other - facilitate the learning process for their participants (students). As research shows, games can be an effective learning environment, because they involve participants to a large extent, require important and often strategic decisions, promote teamwork, encourage skills development and have clearly set goals (Shaffer et al., 2005; Lainema, Lainema, 2007; Oţoiu \& Oţoiu, 2012). Some researchers even show that, according to students at universities, the use of simulation decision games in the didactic process increases the pleasure of the learning process (Buzzetto-More and Bryant, 2009).

It should be added that simulation training games generate many other benefits in various areas, which is related to the way of learning by any person. Phenomena and principles reflecting learning through participation in games are illustrated in Table 3.

Table 3.

Benefits of participating in games

\begin{tabular}{|l|l|l|}
\hline \multicolumn{2}{|c|}{ Phenomena and principles reflecting learning through participation in games } \\
\hline $\begin{array}{l}\text { The right of } \\
\text { reinforcement }\end{array}$ & $\begin{array}{l}\text { We learn these behaviours } \\
\text { that are rewarded }\end{array}$ & $\begin{array}{l}\text { Most games introduce reward systems (e.g. points) that } \\
\text { participants receive when making the right decisions or } \\
\text { actions. Rewards provide feedback that enhances the } \\
\text { desired behaviour. }\end{array}$ \\
\hline $\begin{array}{l}\text { Learning by } \\
\text { emotions }\end{array}$ & $\begin{array}{l}\text { Events that are accompanied } \\
\text { by emotions are remembered } \\
\text { longer. }\end{array}$ & $\begin{array}{l}\text { Training games are one of the most exciting training } \\
\text { methods. In addition, after exciting activities, their analysis } \\
\text { supports learning and drawing conclusions. }\end{array}$ \\
\hline
\end{tabular}


Cont. table 3.

\begin{tabular}{|l|l|l|}
\hline $\begin{array}{l}\text { Active } \\
\text { learning }\end{array}$ & $\begin{array}{l}\text { Active participation leads to } \\
\text { more effective learning than } \\
\text { passive listening or reading. }\end{array}$ & $\begin{array}{l}\text { Games are undoubtedly an active way to develop } \\
\text { competences. }\end{array}$ \\
\hline Leedback & $\begin{array}{l}\text { Learners cannot master their } \\
\text { skills well without proper } \\
\text { feedback. }\end{array}$ & $\begin{array}{l}\text { Feedback is one of the basic conditions for the } \\
\text { construction of training and simulation games and } \\
\text { simulations. Often its role is played by the discussion of } \\
\text { the game, sometimes also by various mechanisms } \\
\text { integrated into the game. }\end{array}$ \\
\hline $\begin{array}{l}\text { Previous } \\
\text { experience }\end{array}$ & $\begin{array}{l}\text { New content should be linked } \\
\text { to the learner's previous } \\
\text { experience. }\end{array}$ & $\begin{array}{l}\text { In the case of games, the participants' prior knowledge and } \\
\text { experience are simply a "contribution" to the game. Games } \\
\text { perfectly combine them with new situations. }\end{array}$ \\
\hline $\begin{array}{l}\text { Individual } \\
\text { differences }\end{array}$ & $\begin{array}{l}\text { Different people learn in } \\
\text { different ways. }\end{array}$ & $\begin{array}{l}\text { Games support different learning styles, ensuring that they } \\
\text { are tailored to participants' preferences in this area. }\end{array}$ \\
\hline Reference & $\begin{array}{l}\text { Effective competence } \\
\text { development refers to the life } \\
\text { and work of learners. }\end{array}$ & $\begin{array}{l}\text { Training games simulate real problems and professional } \\
\text { and personal situations of participants. They pose real } \\
\text { challenges for players. In addition, the discussion of games } \\
\text { aims to develop conclusions useful in the real spheres of } \\
\text { participants' activity and encourages their implementation. }\end{array}$ \\
\hline
\end{tabular}

Social benefits should also be mentioned - games often involve complex communities, thus increasing the added value in the socio-cultural area. In addition, at the start of the game, there is often a need to remind certain information or knowledge gained earlier and to apply it in a new situation. Games also require so-called "transfer" of existing knowledge from other places, e.g. life, work, school and even other games, and connect it with the unique situation that is the core of the game. The analysed didactic tool also allows players to participate in new situations that would otherwise not be available to them - it allows them to play different roles and think, act and talk in various ways - so they can personally experience certain situations rather than rely only on words or symbols. One should not forget about the possibility of gaining experience by participating in simulation training games, because games are inherently empirical and engage many senses (Shaffer et al., 2005).

Researchers also indicate the necessity of participant functioning in a given community, where ideas are shared, problems are defined and solved in a team, and everyone is involved in collective effort and makes a certain contribution to the achievement of the assumed goal. The description of the player community closely reflects the educational community that has a specific, so-called "learning culture", where the emphasis is not only put on learning and developing knowledge and skills, but also on learning how to learn and how to share the knowledge you have or learn with other members of your community. It is not necessary for every member of the community to assimilate everything that the community knows, but everyone should know who has the right knowledge in a given community to solve particular problem - developing such skills is important not only in the game world, but above all in business and non-business life (Bielaczyc, Collins, 1999; Oblinger, 2005).

However, it should be remembered that despite the increasing use of games in training and education, there is still a lack of empirical research that assesses their effectiveness in didactic processes (Dorn, 1989; Sotomayor, Proctor, 2008). Although many researchers have proven 
that the use of games significantly stimulates the motivation and interest of its participants, there is still no evidence for the effectiveness of games as learning tools. This may be due to the fact that most of the claims on this matter are based on the judgment of teachers (Ariffin et al., 2014). There are also few studies, in particular, on the effectiveness of games, which is largely hindered by their complexity and multidimensionality - it is often difficult to capture all variables affecting learning and variables that disrupt learning, and to control all of them. In addition, there are many variables affecting the implementation of new competences in the work environment or in life.

\section{Conclusions}

Due to the fact that simulation decision games are mapping reality using dynamic models (Wawrzyńczyk-Kulik, 2013), they can be used as a tool to support the didactic process carried out in academic conditions. Their essence lies in the fact that the participants take on the roles predicted in the simulation and strive to achieve a measurable result expressed in absolute values (number of points scored) or relative values (achieved position in the ranking), using the powers and resources specified in the game (Kalinowski, 2013), but also possessed knowledge, skills and competences.

The value of simulation decision games in particular evinces itself in solving problems related to cognitive and affective learning and in facilitating interactivity, cooperation, partnership and active learning (Ruben, 1999; Lean et al., 2006).

It can be assumed that the benefits of simulation games in higher education are measurable. By playing we are able to learn many issues in a natural way, to refer to the mechanisms of the organization's functioning, and to use - sometimes dormant - soft competences of game participants. The current use of games has primarily raised awareness of the decision-making problems of managers and other decision-makers. The existence of risk, which is included in the functioning of the organization, gives a sense of simulation of real threats. It cannot be eliminated, you can only assume the probability of its occurrence and be in constant readiness to react.

Therefore, simulation games are an important and useful tool in modern universities, and most likely in the near future they will become an inseparable element of the practical form of classes and will become more and more popular in the teaching process. 


\section{References}

1. Abt, C.C. (1971). Serious Games. New York: Viking.

2. Ariffin, M.M., Oxley, A., Sulaiman, S. (2014). Evaluating Game-Based Learning Effectiveness in Higher Education. Procedia - Social and Behavioral Sciences, 123, 20-27, Doi: 10.1016/j.sbspro.2014.01.1393.

3. Armstrong, R.H.R., and Hobson, M. (1974). Where All Els Fails - An Approach to Defining the Possible Uses of Gaming-simulation in the Decision-making Process. Simulation and Gaming. Proceedings of the 12th Annual Symposium National Gaming Council and the 4th Annual Conference International Simulation and Gaming Association, 204-217.

4. Babb, E.M., Leslie, M.A., Van Slyke, M.D. (1966). The Potential of Business-Gaming Methods in Research. Journal of Business, 39, 465-472.

5. Balcerak, A., and Pełech, A. (2000). Concepts and definitions for simulation nanomodelling. In: Simulation of Economic Systems (pp. 9-23). Warszawa: Kozminski University \& Wrocław University of Science and Technology [in Polish].

6. Ben-Zvi, T. (2010). The efficacy of business simulation games in creating decision support systems: An experimental investigation. Decision Support Systems, 49(1), 61-69. Doi: 10.1016/j.dss.2010.01.002.

7. Bielaczyc, K., and Collins, A. (1999). Learning Communities in Classrooms: A Reconceptualization of Educational Practice. In C. M. Reigeluth (Ed.), Instructional Design Theories and Models: A New Paradigm of Instructional Theory, Vol. II. Mahwah N.J.: Lawrence Erlbaum Associates.

8. Buzzetto-More, N., \& Mitchell, B. (2009). Student performance and perceptions in a webbased competitive computer simulation. Interdisciplinary Journal of E-Learning and Learning Objects, 5, 73-89. Doi: 10.28945/3353.

9. Dorn, D.S. (1989). Simulation Games: One more tool on the Pedagogical Shelf. Teaching Sociology, 17, 1-18. Doi: 10.2307/1317920.

10. Gredler, M.E. (2004). Games and simulations and their relationships to learning. H. Jonassen (Ed.), Handbook of research on educational communications and technology (pp. 571-582). Mahwah, NJ: Erlbaum.

11. Kalinowski, M. (2016). Dilemmas of design and use of simulation games in employee development. Journal of Management and Finance, 14(1), 173-182.

12. Keys, B., and Wolfe, J. (1990). The Role of Management Games and Simulations in Education and Research. Journal of Management, 16, 307-336.

13. Lainema, T., and Lainema, K. (2007). Advancing acquisition of business know-how: Critical learning elements. Journal of Research on Technology in Education, 40(2), 183-198. Doi: 10.1080/15391523.2007.10782504.

14. Larreche, J.-C. (1987). On Simulations in Business Education and Research. Journal of Business Research, 15, 559-571. 
15. Lean, J., Moizer, J., Towler, M., Abbey, C. (2006). Simulations and games. Active Learning in Higher Education. SAGE Publications, 7(3), 227-242. Doi: 10.1177/ 1469787406069056.

16. Metera, A., Pańków, J., Wach, T. (1983). Theoretical and methodical issues of simulative management games. Warszawa: Institute of Organization, Management and Personnel Development [in Polish].

17. Oblinger, D. (2006, August/September). Simulations, games and learning. Educause Review. Retrieved from https://er.educause.edu/articles/2006/1/games-and-learning, 26.03.2019.

18. Oţoiu, C., and Oţoiu, G. (2012). Testing a simulation game as a potential teaching method for a master's course in human resources management. Procedia-Social and Behavioral Sciences, 33, 845-849. Doi: 10.1016/j.sbspro.2012.01.241.

19. Prensky, M. (2001). Digital Game-Based Learning. McGraw-Hill.

20. Ruben, B.D. (1999). Simulations, Games, and Experience Based Learning: The Quest for a New Paradigm for Teaching and Learning. Simulation and Gaming, 30(4), 498-505. Doi: $10.1177 / 104687819903000409$.

21. Shaffer, D.W., Squire K.R., Halverson, R., Gee, J.P. (December 2004). Video Games and the Future of Learning. Retrieved from https://academiccolab.org/resources/ gappspaper1.pdf, 26.03.2019.

22. Sotomayor, T.M., \& Proctor, M.D. (2009). Assessing Combat Medic Knowledge and Transfer Effects Resulting from Alternative Training Treatments. The Journal of Defense Modeling and Simulation: Applications, Methodology, Technology, 6(3), 121-134. Doi:10.1177/1548512909350170.

23. Świtalski, W. (1977). Simulation games. In Application of simulation methods in the chemical industry (pp. 127-146). Warszawa: PTE [in Polish].

24. Szewczak, K. (2015). Training and simulation games. Companion of trainer. N-Biznes Krzysztof Szewczak (The University of Life Sciences in Lublin has a license to use this publication) [in Polish].

25. Tchatcher, D. (1986). Promotion Learning through Games and Simulations. Simulation Games for Learning, 16(4), 144-154.

26. Walkowiak, M. (1981). Simulation decision games - comparison of selected definitions. Simulation of Economic Systems - Trzebieszowice'81 (pp. 203-209). Wrocław-Gliwice: TNOiK \& Institute of Economics of the Chemical Industry [in Polish].

27. Wawrzyńczyk-Kulik, M. (2013). Simulation game as a tool supporting the teaching process within the "Basics of entrepreneurship" subject. Zeszyty Naukowe WSEI, seria: Ekonomia, 6(1), 303-321.

28. Wentzler, I., Chartier, D. (1999). Why Do We Bother with Games and Simulations: An Organizational Learning Perspective. Simulation \& Gaming: An International Journal of Theory, Practice and Research, 30(3), 375-384. Doi: 10.1177/104687819903000315. 